\title{
Research about the Talent Cultivation Mode Integrating Innovation and Entrepreneurship under "Internet +" Environment
}

\author{
Shang Fengjun \\ College of Computer Science and Technology, Chongqing University of Posts and Telecommunications \\ Chongqing 400065
}

\begin{abstract}
Internet + " integrates various industries, and puts forward new requirements for talent quality. With respect to the cultivation of innovation and entrepreneurship talents under "internet+" environment, a series of methods are adopted, including optimizing the cultivation mode, and building the talent cultivation mechanism integrating innovation and entrepreneurship; reinforcing practical education, building the practical teaching mode of industry-education integration, establishing innovation and entrepreneurship quality; innovating teaching methods, perfecting the innovative and entrepreneurship teaching mode lead by teachers and oriented to students; the graduation design closely integrates "internet+" technology, and improves students' operational ability. Through the integrated application of the aforementioned methods, the innovation and entrepreneurship contents can adapt to "internet+" era development requirements; meanwhile, it can also improve the students' innovation and entrepreneurship capacity, and reach to the research objective.
\end{abstract}

Keywords-Internet+; cultivation mode; innovation and entrepreneurship; industry-education integration

\section{INTRODUCTION}

Under the background of the national innovation-driven development strategy, various new business types, new modes, and new products are constantly emerged, and have validly aroused social creativity, and promoted the fast development of national economy. As the base for talent cultivation, the current education mode and education process in colleges cannot well meet the demand for the cultivation of innovation and entrepreneurship talents, and when cultivating talents, they still fail to fully get rid of the status of focusing on theoretical knowledge and paying less attention to practical capacity. Along with the "internet+" concept being put forward, and closely combined with the innovation and entrepreneurship work of all fields at an unprecedented height, this has provided a good opportunity for the professional education work of computer to solve the cultivation problems of innovation and entrepreneurship talents. In order to adapt to the requirements of innovation and entrepreneurship capacity, we mainly conduct research from four aspects, including the course setup, the practice link, the systematic teaching contents and the graduation design.
II. OPTIMIZE THE CULTIVATION MODE, AND BUILD THE TALENT CULTIVATION MECHANISM INTEGRATING INNOVATION AND ENTREPRENEURSHIP

"Internet + " integrates various industries, and puts forward new requirements for talent quality, and we can only cultivate innovation and entrepreneurship talents meeting the new environment through establishing and optimizing the existing talent cultivation mode [1]. The talent cultivation mode refers to the education process and mode for realizing talent cultivation objective and specification through relatively stable teaching contents and course system as well as scientific teaching mode, method and means matched thereby. The innovation and entrepreneurship talents require broad knowledge scope, good knowledge structure, and solid knowledge foundation, and there shall be a diversified cultivation mode that can arouse learning interest, close distance or zero distance contact with the social life as per individual hobbies. It is requested to carefully tease the course system of computer science and technology major, set liberal education platform course system, discipline and specialty basic platform course system, and professional (direction) course system. The liberal education platform course system is set as per the basic course requirements for the undergraduate innovation and entrepreneurship education, the course setup can reflect the innovation and entrepreneurship education concept, and it requests the students to be equipped with science and basic theory accomplishment, and form the systematic view of magnificent or complicated engineering; besides, it can also inspect from multiple disciplines, and is also equipped with humanistic feelings and engineering organization quality. As a classic discipline, computer science and technology not only involves dynamics, electricity and other natural science, but also involves laws, humanity, psychology, management and other disciplines, with strong subject overlapping, integrity and practicalness. On the basis of rationalizing the teaching contents, various courses shall take the completion of basic computer system design and realization as the teaching objective, and improve the teaching method. While reinforcing conceptual knowledge explanation, it is requested to reinforce the training of engineering realization method, and strive to let students obtain certain knowledge in system principle and engineering realization method. 


\section{REINFORCE PRACTICAL EDUCATION, BUILD INDUSTRY- EDUCATION INTEGRATED PRACTICAL TEACHING MODE, AND ESTABLISH INNOVATION AND ENTREPRENEUR QUALITY}

"Internet+" has a higher requirement for talents' operational ability, and it requires the reinforcement of practical education, and the integration of various resources inside and outside of the school. Practical education is not only a teaching method, but also a teaching link. It takes the professional skill training as the main contents and the practical innovation and entrepreneurship capacity cultivation as the objective, ad meanwhile, adopts teacher guidance, and the active participation of students as the main teaching method, and it is the important channel for students to convert knowledge into capacity, and applying theory in practice [2]. Therefore, the reinforcement of practical education is the important link for cultivating students' innovation and entrepreneurship capacity.

\section{A. Systematically build practical teaching system based on capacity cultivation}

Conduct innovation based on inheriting the traditional contents, and then through the integration of original practical link, realize the overall optimization of practical teaching contents system, and confirm the practical teaching system that emphasizes on four links, including the course practice, investigation practice, thesis design and extracurricular practice meanwhile, take the four gradually progressive stairs of public practice, discipline practice, professional practice and comprehensive practice as the layers, adhere to the ceaseless four-year practical teaching, and make the practical teaching run through the entire learning process of the undergraduate period.

\section{B. Update and optimize the practical teaching contents}

To further reinforce the cultivation of students' comprehensive capacity, and innovation capacity, it is requested to take the capacity cultivation as the main line to build practical teaching contents system, and constantly update and optimize the practical teaching contents; scientifically design the experiment contents, and reinforce innovative experiment contents [3], ensure that the students can obtain innovation capacity training in experiment teaching link; constantly expand students' autonomous experiment, so as to reinforce the students' capacity to conduct innovative experiments.

\section{INNOVATE TEACHING METHOD, AND PERFECT THE INNOVATION AND ENTREPRENEURSHIP TEACHING MODE LED BY TEACHERS AND ORIENTED TO STUDENTS}

"Internet + " integrates the knowledge of various industries, and requests certain changes in teaching methods, so as to adapt to the students' demand for innovation and entrepreneurship knowledge. The teaching method is the main factor restricting the students' innovation capacity development The cultivation of innovation and entrepreneurship talents cannot be separated from revolution and innovation, and the innovation of education concept can promote the comprehensive innovation of teaching contents, teaching modes and teaching technologies [4]. The teaching mode must realize the transformation from the traditional knowledge teaching mode centered on teachers to the teaching mode that combines knowledge teaching, innovation and practice, possesses the interaction between teachers and students, mutual benefits to teachers and students, and takes the mobilization of students' autonomous learning, the motivation of students' thirst for knowledge and creativity as the main objective.

\section{A. Emphasize on the advancement and novelty of teaching contents}

To cultivate students' innovation capacity, it is requested to constantly update the teaching contents, let students master the newest knowledge, understand the world's newest development status, and make the students' knowledge layer and structure be synchronized with the world's development advanced level, and only then can the students realize innovation and breakthrough based on the existing level. This will request the reinforcement in the promotion force of scientific research for teaching, the integration of more scientific research achievements in course teaching contents, and the application in teaching practice.

\section{B. Build practical innovation and entrepreneurship plan for undergraduate students}

Currently, Chongqing University of Posts and Telecommunications has carried out many practical and scientific research activities, but the effect for students to effectively participate in the activity, and obtain the effect of practical innovation capacity is more obvious, but it still needs to be reinforced. The exploration will combine the various extracurricular learning, and practice activities of students into "undergraduate innovation plan", which shall specifically include: the scientific research innovation training plan mainly refers to organizing and carrying out various scientific research activities, including the college students scientific research project approval, the college students' innovation and entrepreneurship training project, the participation of teachers topic research, the invention patent application, open experiment training and other activities; the science and technology competition plan mainly refers to organizing and participating in "challenge cup", students" modeling competition and science and technology competition as well as other competitions of various disciplines; the comprehensive quality improvement plan mainly refers to participating in humanities and social sciences category of lectures, recreational and sports activities, the school club activities, 
summer social practice, etc.; the professional skill training plan mainly refers to encouraging the students to participate in foreign language capacity, computer application capacity and various kinds of professional qualification, professional skill training and certificate test activities; the practice base internship plan mainly refers to making students formulate practice base participation and work practice within a certain time, complete certain workload, or complete certain knowledge level of internship report. The practice innovation plan of college students is based on the principle of "overall design, and sub-item implementation", implements project responsibility system, and adopts the method of "project management" to organize the implementation. The plan will run through the entire cultivation process, and will be opened in each semester repeatedly, and realized the unceasing fouryear implementation; students can select the relevant projects and the studying time as per their own hobbies, capacity and specialties. In order to ensure the valid implementation of practice innovation plan, a set of operation management system is built, to ensure that the innovation learning plan can be validly implemented. The college will take the lead, and be responsible for implementing the practice innovation plan of college students, and integrating the existing tutor system, excellent engineer cultivation system, youth league committee, the department of student affairs and other social practice related regulations of the school, and formulating the practice innovation plan implementation management methods for college students and various sub-item objectives organization and implantation management methods and detailed rules. The aforementioned contents are included into the training scheme as per the mode of "innovation credit".

\section{THE GRADUATION DESIGN CLOSELY INTEGRATES "INTERNET+" TECHNOLOGY, AND CAN IMPROVE THE INNOVATION AND ENTREPRENEURSHIP CAPACITY}

To improve the Integrating degree of computer science and technology with the society, the graduation design (thesis) topic selection shall be closely combined with the actual engineering problems of "internet + " as much as possible, and make students learn how to apply their learned knowledge in the process of solving actual problems; as for the topic selection, guidance and assessment of graduation design (thesis), there shall be the participation of enterprise and industrial experts.

\section{A. Reinforce the proportion of engineering type of topics in the graduation design topic selection}

Through the reform of the graduation design (thesis) marking standard and the college evaluation system, it is requested to formulate incentive measures. On one hand, as per the enterprise demands, it is requested to reinforce the proportion of innovative topic selection that can be closely combined with the actual engineering problems of the major. On the other hand, it is requested to encourage teachers to convert their own scientific research achievements in the graduation design topic selection, and create conditions for students to contact with the leading science and technology of the industry, and cultivate innovative research capacity.

\section{B. Build "double-teacher" type graduation design guidance team}

The graduation design adopts two modes, including the independent guidance of teachers inside the school and the "double-teacher" guidance of school and enterprise. The students can voluntarily select one of the guidance modes. The "double-teacher" guidance of school and enterprise refers to the mode that the school hires enterprise experts as the offcampus guidance teachers of students for the graduation design, and they will jointly complete the guidance work with the teachers inside the school, and the students can participate in the technical $R \& D$ project of the enterprise at the practice base cooperating with the school, and complete the graduation design task. As for the independent guidance mode of teachers inside the school, enterprise experts will be invited to participate in the review and defense, and the grade of comprehensive enterprise experts and teachers inside the campus will be taken as the final achievements. Through the participation of business circles in the evaluation, it can promote the good combination of graduation design and engineering application demand, and promote the improvement of graduation design quality.

\section{Open laboratory, and research institute, and absorb undergraduate students to the laboratory and $R \& D$ team}

The cultivation of innovation and entrepreneurship capacity is the important focus for improving the undergraduate teaching level of computer major, of which the important thing is the concept transformation of teachers, and the awareness improvement as well as the design of course system and experiment contents suitable for students of the school. Since the computer technology involves wide contents, and the equipment of teaching and management team is dynamic, in the teaching team of professional direction, course group and other different layers, it is requested to encourage and attract more teachers with high scientific research level, and strong engineering capacity to go deep into the first line of practical teaching and management. Meanwhile, it is also an important approach to introduce the enterprise senior engineers to participate in practical teaching to improve the engineering practice capacity of students. To sum up, it is requested to adopt self-improvement, enterprise cooperation, scientific research combination and other modes, which can be good for improving the overall technical level and teaching capacity of the team. 


\section{SUMMARY}

"Internet+" integrates various industries, and puts forward new requirements for talent quality, and it is requested to establish and optimize the existing talent cultivation mode, to cultivate innovation and entrepreneurship talents meeting the new environment. The talent cultivation mode refers to the teaching process and mode for using relatively stable teaching contents and course system as well as the matched scientific teaching mode, methods and means to realize the talent cultivation objective and specification. The innovation and entrepreneurship talents request wide scope of knowledge, good knowledge structure, solid knowledge foundation, and there shall be a diversified cultivation mode that can arouse learning interest, and contact with the social life at a short distance or zero distance as per personalities and hobbits. "Internet+" has a higher requirement for talents' operational capacity, and it is requested to reinforce practical education, and integrate various resources inside and outside of the school. Practical education is not only a teaching method, but also a teaching link. "Internet+" integrates the knowledge of various industries, and requests certain changes in teaching method, so as to adapt to the students' demand for innovation and entrepreneurship knowledge. The teaching method is the main factor restricting students' innovation capacity development. The cultivation of innovation and entrepreneurship talents cannot be separated from reform and innovation, and it uses the innovation of education concept, to promote the comprehensive innovation of teaching contents, teaching methods and teaching technologies. In order to improve the integrating degree of computer science and technology major with the society, the graduation design (thesis) topic selection shall be closely combined with the actual engineering problems of "internet + " as much as possible, so as to let students learn how to apply their learned knowledge in the process of solving actual problems, and as for the graduation design (thesis) topic selection, guidance and evaluation, there shall be the participation of enterprise or industrial experts.

\section{ACKNOWLEDGMENT}

Many thanks to the subsidy of Chongqing Higher Education and Teaching Reform (Project No.: 173068), and the subsidy of Chongqing University of Posts and Telecommunications Education and Teaching Reform Research Project (Project No.: XJG1513).

\section{REFERENCES}

[1] Wang Yingyun. Course Teaching Reform and Research of Computer Network Application Technology under the Era of Internet+[J]. Journal of Chifeng University (Natural Science Edition), 2016, 32(21): 230-231.

[2] Lin Yezhi. Industry-education Integrated Multi-track Practical Teaching Mode Exploration and Practice Oriented to Professional Capacity [J]. Journal of Hubei Radio \& Television University, 2016, 36(2): 12-16.

[3] Cao Di. Breaking the Constraint of Traditional Teaching Concept, and Cultivating Innovative and Entrepreneurial Talents [J]. Reading, Writing and Calculating: Teacher Version, 2016 (42) :13-13.

[4] Song Hongguang, Xu Dali, and Hou Chang. Computer Network Practical Teaching Reform Research under Internet [J]. Course Education Research, 2016, (36): 19-20. 